\title{
The Application of Starling's Law of Capillary Exchange to the Lungs*
}

\author{
O. Robert Levine,† Robert B. Mellins, $\ddagger$ Robert M. Senior,§ and \\ Alfred P. Fish MAN \|
}

(From the Departments of Pediatrics and Medicine of the College of Physicians \& Surgeons, Columbia University, New York, N. Y.)

Summary. The forces governing the movement of water across the pulmonary capillaries were studied in 39 intact, spontaneously breathing dogs. A situation favoring the net movement of water out of the pulmonary capillaries was created by means of partial pulmonary venous obstruction (left atrial balloon catheter) followed by rapid saline hemodilution. A predetermined difference between pulmonary capillary and plasma colloid osmotic pressures was maintained for periods of 1 to 2 hours. Left atrial $\left(P_{L A}\right)$ and plasma colloid osmotic pressures $\left(\pi_{\mathrm{pl}}\right)$ were measured directly. The water content of the lungs was measured serially by an indicator-dilution technique, and at autopsy by drying the lungs. The rate of accumulation of lung water was measured in four groups of animals: in three of the groups, the capillary hydrostatic and colloid osmotic pressures were varied; in the fourth group, the right lymphatic duct was obstructed in addition.

The average rate of water accumulation in the lungs varied in a nonlinear way with the level of the capillary hydrostatic-plasma colloid osmotic pressure difference and was unaffected by the level of the capillary hydrostatic pressure. At low levels of $\mathrm{P}_{\mathrm{LA}}-\pi_{\mathrm{pl}}$, water accumulated in the lung at an average rate of $0.09 \mathrm{~g}$ per $\mathrm{g}$ dry lung per hour per $\mathrm{mm} \mathrm{Hg}$ pressure difference. At higher levels of $P_{\mathrm{LA}}-\pi_{\mathrm{pl}}$ the average rate of accumulation was $0.22 \mathrm{~g}$ per g per hour per $\mathrm{mm} \mathrm{Hg} \Delta \mathrm{P}$; in most of the experiments in this group water accumulated in the lungs slowly during the first 30 minutes of the test period and more rapidly as the period was extended. Obstruction of right lymphatic duct outflow did not alter the rate of water accumulation. Based on the control data of the present experiments, the pericapillary pressure in normal lungs is estimated to be of the order of $-9 \mathrm{~mm} \mathrm{Hg}$ in the normal dog lung. The filtration coefficient for the pulmonary capillaries is estimated to be of the order of one-tenth to one-twentieth of that for canine muscle capillaries. The data of the present study indicate that edema formation in lung tissue cannot be defined solely in terms of intravascular forces, but may be governed to a significant degree by changes in pericapillary forces in the pulmonary interstitium.

\footnotetext{
* Submitted for publication June 20, 1966; accepted February 17, 1967.

Supported by research grants HE-05741 and HE-08015 from the National Institutes of Health, U. S. Public Health Service, with additional support from the New York Heart Association and the Health Research Council of the City of New York, contract U-1613.

Presented at the May 1965 meeting of the Society for Pediatric Research, Philadelphia, $\mathrm{Pa}$.
}

$\dagger$ Recipient of a New York City Health Research Council Career Scientist Award, contract I-259.

$\ddagger$ Recipient of Career Development Award 1-K3-He31,667-01 from the National Institutes of Health.

$\S$ Research fellow of the U. S. Public Health Service. II Address requests for reprints to Dr. Alfred P. Fishman, Dept. of Medicine, University of Chicago, Chicago, IIl. 60637 . 


\section{Introduction}

Starling's law of transcapillary exchange defines the forces governing the bulk movement of water between the vascular and the extravascular compartments (1). According to this law the transcapillary movement of fluid is the consequence of an imbalance between opposing filtrative and absorptive forces; the magnitude of the net transfer is a function of the filtration coefficient, $\mathrm{k}(2)$.

Fluid movement $\doteq \mathrm{k}\left(\mathrm{Pc}+\pi_{\mathrm{if}}-\mathrm{P}_{\mathrm{if}}-\pi_{\mathrm{pl}}\right)$, where $\mathrm{k}=$ filtration coefficient (milliliters per second per square centimeter per millimeter $\mathrm{Hg} \Delta \mathrm{P}$ ), $\mathrm{Pc}=$ capillary hydrostatic pressure (millimeters $\mathrm{Hg}), \pi_{\text {if }}=$ osmotic pressure of interstitial fluid proteins (millimeters $\mathrm{Hg}$ ), $\mathrm{P}_{\mathrm{if}}=$ pericapillary hydrostatic pressure (millimeters $\mathrm{Hg}$ ), and $\pi_{\mathrm{pl}}=$ osmotic pressure of plasma proteins (millimeters $\mathrm{Hg}$ ).

Although it is not always possible to demonstrate the operation of Starling's law in single capillaries (3), it is generally agreed that this formulation does account for the forces governing the transcapillary exchange of water in tissues (2).

The recent studies of Guyton and Lindsey indicate that Starling's law of transcapillary exchange also applies to the lungs (4). In these studies, the accumulation of water in lung tissue of dogs was found to be directly related to the intravascular forces $\left(\mathrm{P}_{\mathrm{LA}}-\pi_{\mathrm{pl}}\right)$; pericapillary forces exerted a negligible influence. Moreover, by setting the interstitial forces $\left(\pi_{1 f}-P_{1 f}\right)$ equal to zero, and solving the Starling equation, they derived a filtration coefficient for the capillaries of the dog lung, viz., $0.22 \mathrm{~g}$ per $\mathrm{g}$ dry lung per hour per $\mathrm{mm} \mathrm{Hg} \Delta \mathrm{P}$ (4).

In the course of studies designed to quantify pulmonary edema in the intact dog by a special application of the indicator-dilution principle (5), we noted, in contrast to the results of Guyton and Lindsey, that the rate of increase in the water content of lung tissue was not linearly related to the intravascular forces $\left(\mathrm{P}_{\mathrm{LA}}-\pi_{\mathrm{pl}}\right)$, implying that unmeasured forces, which they had considered to be negligible, were actually exerting appreciable effects. In keeping with our experimental observations were both clinical and theoretical considerations: 1) The high levels of
$\mathrm{P}_{\mathbf{L A}}-\pi_{\mathrm{pl}}$ are frequently not associated with pulmonary edema in man (6-8); these exceptions have been attributed either to a decrease in capillary permeability (9) or to an expanded lymphatic drainage. 2) The force exerted by surface tension at the pulmonary air-fluid interface, which presumably affects pericapillary (and therefore transcapillary) pressure (10), would be expected to change progressively during pulmonary edema $(11,12)$.

To assess the importance of pericapillary forces in governing the transcapillary filtration of water in the lungs, we undertook a systematic study of Starling's law as applied to the pulmonary capillaries. From these studies, we were able to estimate the filtration coefficient of the fluid-exchanging vessels of the lungs and to appraise its meaning as a measure of pulmonary "capillary permeability."

\section{Methods}

Thirty-nine mongrel dogs weighing 8 to $18 \mathrm{~kg}$ were anesthetized with intravenous pentobarbital, $25 \mathrm{mg}$ per $\mathrm{kg}$ of body weight. The trachea was intubated with a cuffed endotracheal tube. The animals were placed in the prone position with the forelimbs and pelvis supported off the table, so that breathing would not be mechanically restricted. Breathing was spontaneous, but the lungs were fully inflated every 10 minutes by a Bird respirator.

A standard experimental procedure was used to promote the extravascular accumulation of lung water. This involved the combination of pulmonary venous hypertension and hemodilution (5). Partial pulmonary venous obstruction was produced by passing a double-lumen, end-hole balloon catheter retrogradely, under fluoroscopic control, through the aortic and mitral valves, and inflating the balloon in the left atrium with $3.5 \mathrm{ml}$ of radiopaque material. Hemodilution and pulmonary venous (and capillary) hypertension were rapidly produced by the intravenous infusion of isotonic saline. Left atrial pressure was measured through the hole in the end of the balloon catheter. Other catheters were also placed under fluoroscopic control for the measurement of pulmonary arterial, aortic arch, and right atrial pressures (5). All vascular pressures were measured with Statham $\mathrm{P} 23 \mathrm{Db}$ strain gauges and recorded on a multichannel photographic recorder (Electronics for Medicine model DR8). The zero reference level for the pulmonary arterial and the left atrial pressures was the tip of the respective catheters as determined fluoroscopically; each gauge was calibrated during each experiment with a mercury manometer. For the purpose of this study, the pulmonary capillary pressure was considered to be identical to the pulmonary venous and left atrial pressures $\left(P_{L A}\right)$. The pulmonary transcapillary pressure differ- 
ence $\left(P_{L A}-\pi_{p 1}\right)$ is therefore defined as the difference between the left atrial pressure and the plasma colloid osmotic pressure $\left(\pi_{\mathrm{pl}}\right)$.

The left atrial and pulmonary arterial pressures were monitored continuously during each experiment. At 15to 30-minute intervals, systemic arterial blood samples were drawn; measurements were made of blood $\mathrm{pH}$ and gases, hematocrit, total proteins, and plasma colloid osmotic pressure. Oxygen saturation was measured by the method of Van Slyke and Neill and the $\mathrm{PCO}_{2}$ was measured from the arterial $\mathrm{CO}_{2}$ content and $\mathrm{pH}$ by the line charts of Van Slyke and Sendroy. Total serum protein concentration was obtained by means of a Hitachi hand refractometer (13). The colloid osmotic pressure was measured directly with a Hepp-Brown osmometer (2).

Two methods were employed for the determination of the amount of water in the lungs. The first was the double indicator-dilution technique of Chinard and Enns (14), using $\mathrm{T}-1824$ as the nondiffusible indicator and tritiated water as the diffusible indicator, as previously described from this laboratory (5). By this approach an extravascular volume of distribution of tritiated water in the lungs (VTHOL) is calculated as the difference between the volume of dilution of tritiated water (Vтно) and of T-1824 ( $\left.\mathrm{V}_{\mathrm{T}-1824}\right)$. This technique permits serial measurements of lung water during the course of an experiment. Previous work in this laboratory has shown that this single-circulation indicator-dilution volume consistently measures approximately onehalf of the total lung water, both in normal and edematous lungs (5).

The recovery of tritiated water from the aorta after the injection of $30 \mu \mathrm{c}$ into the main pulmonary artery was measured 20 times in 10 dogs under control conditions of these experiments, and 20 times in 10 dogs that had various degrees of experimentally induced pulmonary edema. The average recovery during control conditions was $28.4 \mu \mathrm{c}(\mathrm{SE}=1.1)$ and during pulmonary edema was $30.7 \mu \mathrm{c}(\mathrm{SE}=0.8)$. The difference between these means was not statistically significant.

The recovery of tritiated water relative to $T-1824$ was determined by plotting the simultaneous T-1824 and tritiated water concentrations as fractions of the administered dose of each indicator. The resulting single-circulation, time-concentration curves were corrected for recirculation by means of a semilogarithmic plot, in the conventional manner (14). The areas under the corrected simultaneous curves were compared 10 times in 5 dogs under control conditions, and 10 times in 5 dogs with pulmonary edema; they agreed within $10 \%$ in all instances.

The value for VTHOL in normal dogs was found to be $3.5 \pm 0.9 \mathrm{ml}$ per $\mathrm{kg}$ body weight, and increments of $2 \mathrm{ml}$ per $\mathrm{kg}$ body weight or more could be detected reliably (5).

The second method involved the direct measurement of the total amount of water in the lungs at autopsy. The animal was exsanguinated and the lungs were removed and drained of their residual blood by a combina- tion of gravity and gentle milking, care being taken to conserve any fluid issuing from the airways. The bloodless lungs were then weighed before and after dehydration. The increment in total lung water was calculated for each animal as the difference between the water content of the lungs at autopsy, in grams of water per gram of dry lung, and the average value for the water content of the lungs of 10 normal dogs whose lungs had been prepared in exactly the same way; in these 10 control dogs, the total lung water averaged $3.6 \mathrm{~g}$ of water per $\mathrm{g}$ of dry lung $(S E=0.2)$. The rates of accumulation of lung water were calculated per hour of experimental period, and were expressed in terms of per unit average pressure difference $\left(\mathrm{P}_{\mathrm{LA}}-\pi_{\mathrm{p} 1}\right)$ during each experiment. In practice, the following formulation was used: Rate of accumulation $=$ [total lung water (grams per gram dry lung) -3.6 (grams per gram dry lung)]/[duration (hours) $\times$ average $\left(\mathrm{P}_{\mathrm{LA}}-\pi_{\mathrm{p} 1}\right)$ (millimeters $\mathrm{Hg}$ )] .

The sequence of events was as previously described (5). After the catheters had been positioned, the control blood pressures were recorded, blood samples were drawn, and the double indicator-dilution study was done in duplicate. The left atrial balloon was then inflated, and a rapid intravenous infusion of warmed isotonic saline into the right atrium was begun. The left atrial pressure increased abruptly, whereas the hematocrit, the concentration of serum proteins, and the colloid osmotic pressure of the plasma decreased. By adjusting the speed of infusion, we set the level of pulmonary venous hypertension at a predetermined level, always appreciably higher than mean alveolar pressure, for the duration of the experiment. The indicator-dilution study was repeated, in duplicate, at the midway point and at the end of the experiment. At the close of the experiment the infusion was stopped, the dog was rapidly exsanguinated, and the lungs were removed and analyzed for their water content.

Four variations of this experimental design were used, as shown in Table I.

Group I (low pressure, low gradient). In 9 dogs, the left atrial pressure was maintained at 14 to $22 \mathrm{~mm}$ $\mathrm{Hg}$, and the colloid osmotic pressure of the plasma at 3 to $10 \mathrm{~mm} \mathrm{Hg}$ during a 2-hour saline infusion. The transcapillary pressure differences $\left(P_{L 1}-\pi_{p 1}\right)$ ranged from 4 to $17 \mathrm{~mm} \mathrm{Hg}$, with an average of $12 \mathrm{~mm} \mathrm{Hg}$.

Group II (high pressure, high gradient). In 13 dogs, the left atrial pressure was maintained at 23 to $35 \mathrm{~mm}$ $\mathrm{Hg}$ and the colloid osmotic pressure of the plasma at 2 to $8 \mathrm{~mm} \mathrm{Hg}$ during a 1-hour saline infusion. The transcapillary pressure differences ranged from 18 to $32 \mathrm{~mm}$ $\mathrm{Hg}$, with an average of $25 \mathrm{~mm} \mathrm{Hg}$.

Group III (high pressure, low gradient). In 6 animals the left atrial pressure was maintained at 25 to 32 $\mathrm{mm} \mathrm{Hg}$ and the colloid osmotic pressure of the plasma at 12 to $20 \mathrm{~mm} \mathrm{Hg}$ during a 2-hour infusion of $6 \%$ dextran in isotonic saline. The transcapillary pressure difference ranged from 10 to $19 \mathrm{~mm} \mathrm{Hg}$, with an average of $13 \mathrm{~mm} \mathrm{Hg}$.

Group IV (lymphatic obstruction). In $11 \mathrm{dogs,} \mathrm{right}$ lymphatic duct drainage was obstructed before the test 
PULMONARY EDEMA AND PERICAPILLARY PRESSURE

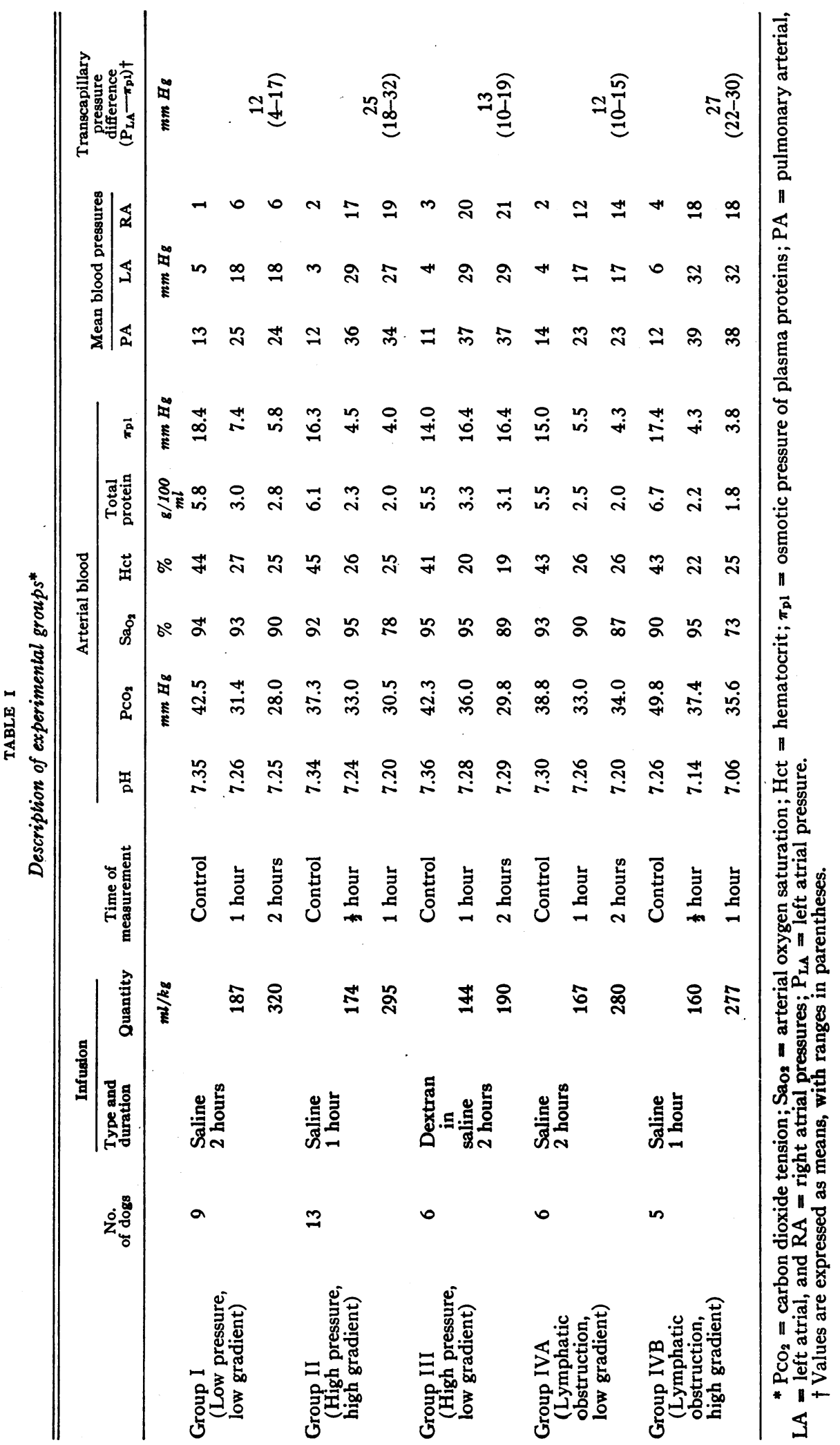


periods. Through a cervical incision the right external jugular, the right subclavian, and the innominate veins were isolated and ligated. All surrounding tissue was thoroughly cauterized with an electrocautery. Immediately after this procedure, the protocol of group I was used in 6 animals (group IVA) and of group II in 5 additional animals (group IVB).

\section{Results}

Group I (low pressure, low gradient). In each of the 9 dogs in which the left atrial pressure exceeded the colloid osmotic pressure of the plasma by 4 to $17 \mathrm{~mm} \mathrm{Hg}$ for a period of 2 hours, the water content of the lungs determined at autopsy was abnormally high. The difference between the average water content at autopsy $(5.6 \mathrm{~g}$ per $\mathrm{g}$ dry lung, $\mathrm{SE}=0.3$ ) and the average of 10 control determinations of total lung water $(3.6 \mathrm{~g}$ per $\mathrm{g}$ dry lung, $\mathrm{SE}=0.2)$ is statistically significant $(\mathrm{p}<$ $0.01)$. The average rate of accumulation was 0.9 $\mathrm{g}$ per $\mathrm{g}$ dry lung per hour $(\mathrm{SE}=0.2)$, or $0.09 \mathrm{~g}$ per $\mathrm{g}$ per hour per $\mathrm{mm} \mathrm{Hg}$ transcapillary pressure difference $(\mathrm{SE}=0.01$ ) (Table II). Comparison of the measurements of extravascular lung water by the indicator-dilution technique $\left(\mathrm{VTHO}_{\mathrm{L}}\right)$ during the control period and at 1 hour and 2 hours shows no significant differences $(p>0.05)$ (Table II).

Group II (high pressure, high gradient). When the left atrial pressure exceeded the colloid osmotic pressure of the plasma by 18 to $32 \mathrm{~mm} \mathrm{Hg}$, water accumulated in the lungs at such a rate that the experiments could not be prolonged beyond 1 hour. Based on determinations of the water content of the lungs at autopsy, the rate of accumulation of water in these dogs averaged 5.6 $\mathrm{g}$ per $\mathrm{g}$ per hour $(\mathrm{SE}=0.8)$, or $0.22 \mathrm{~g}$ per $\mathrm{g}$ per hour per $\mathrm{mm} \mathrm{Hg} \Delta \mathrm{P}(\mathrm{SE}=0.03)$. Comparison of the mean rates of water accumulation in groups I and II, calculated from the water content of the lungs at autopsy and expressed per hour of ex-

TABLE II

The quantity and rate of accumulation of water in the lungs*

\begin{tabular}{|c|c|c|c|c|c|c|c|c|c|}
\hline & \multirow{2}{*}{$\begin{array}{c}\text { No. } \\
\text { of dogs }\end{array}$} & \multirow{3}{*}{$\begin{array}{c}\text { Time of } \\
\text { measurement }\end{array}$} & \multicolumn{4}{|c|}{ Indicator-dilution studies } & \multirow{2}{*}{$\begin{array}{l}\text { Total } \\
\text { lung } \\
\text { water }\end{array}$} & \multirow{2}{*}{\multicolumn{2}{|c|}{$\begin{array}{l}\text { Rate of accumulation } \\
\text { of lung water }\end{array}$}} \\
\hline & & & $\dot{\mathbf{Q}}$ & $\mathrm{VTT}-1824$ & Vтно & $\mathrm{VTHO}_{\mathrm{L}}$ & & & \\
\hline \multirow{4}{*}{$\begin{array}{l}\text { Group I } \\
\text { (Low pressure, } \\
\text { low gradient) }\end{array}$} & \multirow{4}{*}{9} & & $\mathrm{ml} / \mathrm{min} / \mathrm{kg}$ & $m l / k g$ & $\mathrm{ml} / \mathrm{kg}$ & $m l / k g$ & $g / g \dagger$ & $\mathrm{g} / \mathrm{g} /$ hour & $\begin{array}{l}g / g / h o u r / \\
m m H g \Delta P\end{array}$ \\
\hline & & Control & $\begin{array}{l}167 \\
(19)\end{array}$ & $\begin{array}{c}13.3 \\
(1.2)\end{array}$ & $\begin{array}{c}16.8 \\
(1.4)\end{array}$ & $\begin{array}{c}3.5 \\
(0.3)\end{array}$ & & & \\
\hline & & 1 hour & $\begin{array}{l}311 \\
(23)\end{array}$ & $\begin{array}{c}19.5 \\
(1.3)\end{array}$ & $\begin{array}{l}23.5 \\
(1.4)\end{array}$ & $\begin{array}{c}4.0 \\
(0.3)\end{array}$ & & & \\
\hline & & 2 hours & $\begin{array}{l}259 \\
(30)\end{array}$ & $\begin{array}{l}19.5 \\
(1.1)\end{array}$ & $\begin{array}{l}23.9 \\
(1.3)\end{array}$ & $\begin{array}{c}4.4 \\
(0.4)\end{array}$ & $\begin{array}{c}5.6 \\
(0.3)\end{array}$ & $\begin{array}{c}0.9 \\
(0.2)\end{array}$ & $\begin{array}{c}0.09 \\
(0.01)\end{array}$ \\
\hline $\begin{array}{l}\text { Group II } \\
\text { (High pressure, } \\
\text { high gradient) }\end{array}$ & 13 & $\begin{array}{l}\text { Control } \\
\text { hour } \\
1 \text { hour }\end{array}$ & $\begin{array}{l}160 \\
(26) \\
337 \\
(31) \\
306 \\
(28)\end{array}$ & $\begin{array}{l}13.3 \\
(1.2) \\
22.5 \\
(1.5) \\
21.6 \\
(1.3)\end{array}$ & $\begin{array}{l}16.3 \\
(1.3) \\
27.1 \\
(1.6) \\
30.0 \\
(1.5)\end{array}$ & $\begin{array}{l}3.0 \\
(0.2) \\
4.6 \\
(0.5) \\
8.4 \\
(0.9)\end{array}$ & $\begin{array}{c}9.3 \\
(0.8)\end{array}$ & $\begin{array}{l}5.6 \\
(0.8)\end{array}$ & $\begin{array}{c}0.22 \\
(0.03)\end{array}$ \\
\hline \multirow{2}{*}{$\begin{array}{c}\text { Group III } \\
\text { (High pressure, } \\
\text { low gradient) }\end{array}$} & \multirow[t]{2}{*}{6} & Control & $\begin{array}{l}129 \\
(15)\end{array}$ & $\begin{array}{c}12.8 \\
(1.5)\end{array}$ & $\begin{array}{l}16.8 \\
(1.5)\end{array}$ & $\begin{array}{c}4.0 \\
(0.3)\end{array}$ & & & \\
\hline & & $\begin{array}{l}1 \text { hour } \\
2 \text { hours }\end{array}$ & $\begin{array}{l}328 \\
(31) \\
322 \\
(28)\end{array}$ & $\begin{array}{l}21.5 \\
(3.0) \\
23.9 \\
(2.5)\end{array}$ & $\begin{array}{l}26.0 \\
(3.1) \\
30.7 \\
(2.4)\end{array}$ & $\begin{array}{l}4.5 \\
(0.4) \\
6.8 \\
(0.4)\end{array}$ & $\begin{array}{l}5.8 \\
(0.1)\end{array}$ & $\begin{array}{l}1.0 \\
(0.2)\end{array}$ & $\begin{array}{c}0.09 \\
(0.02)\end{array}$ \\
\hline \multirow{3}{*}{$\begin{array}{l}\text { Group IVA } \\
\text { (Lymphatic } \\
\text { obstruction, } \\
\text { low gradient) }\end{array}$} & \multirow[t]{3}{*}{6} & Control & $\begin{array}{l}148 \\
(29)\end{array}$ & $\begin{array}{c}11.6 \\
(0.9)\end{array}$ & $\begin{array}{c}14.9 \\
(1.0)\end{array}$ & $\begin{array}{c}3.3 \\
(0.3)\end{array}$ & & & \\
\hline & & $\begin{array}{l}1 \text { hour } \\
2 \text { hours }\end{array}$ & $\begin{array}{l}241 \\
(39) \\
231\end{array}$ & $\begin{array}{l}16.2 \\
(1.1) \\
15.4\end{array}$ & $\begin{array}{l}20.8 \\
(1.4) \\
21.0\end{array}$ & $\begin{array}{c}4.6 \\
(0.7) \\
5.6\end{array}$ & & & \\
\hline & & 2 hours & $\begin{array}{l}231 \\
(29)\end{array}$ & $\begin{array}{l}1.4 \\
(1.9)\end{array}$ & $(2.0)$ & $(0.7)$ & $\begin{array}{l}6.2 \\
(0.2)\end{array}$ & $(0.1)$ & $(0.01)$ \\
\hline \multirow{3}{*}{$\begin{array}{l}\text { Group IVB } \\
\text { (Lymphatic } \\
\text { obstruction, } \\
\text { high gradient) }\end{array}$} & \multirow[t]{3}{*}{5} & Control & $\begin{array}{l}116 \\
(14)\end{array}$ & $\begin{array}{c}9.7 \\
(1.1)\end{array}$ & $\begin{array}{l}12.2 \\
(1.4)\end{array}$ & $\begin{array}{c}2.5 \\
(0.4)\end{array}$ & & & \\
\hline & & hour & $\begin{array}{l}246 \\
(12)\end{array}$ & $\begin{array}{l}17.2 \\
(1.1)\end{array}$ & $\begin{array}{l}20.8 \\
(1.1)\end{array}$ & $\begin{array}{l}3.6 \\
(0.3)\end{array}$ & & & \\
\hline & & 1 hour & $\begin{array}{l}212 \\
(21)\end{array}$ & $\begin{array}{l}15.6 \\
(0.7)\end{array}$ & $\begin{array}{l}22.1 \\
(1.2)\end{array}$ & $\begin{array}{l}6.5 \\
(0.7)\end{array}$ & $\begin{array}{c}9.2 \\
(1.8)\end{array}$ & $\begin{array}{l}5.5 \\
(1.8)\end{array}$ & $\begin{array}{c}0.21 \\
(0.07)\end{array}$ \\
\hline
\end{tabular}

*Values are presented as means, with standard errors in parentheses. $\dot{Q}=$ cardiac output; $V_{T-1824}=$ single-circulation indicator-dilution

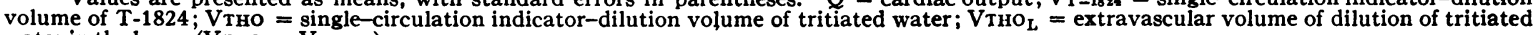
water in the lungs $\left(V_{T H O}-V_{T-1824}\right)$. 
perimental period, shows the difference to be statistically significant $(p<0.01)$.

The rate of accumulation of lung water in groups $I$ and II is related to the mean $\mathrm{P}_{\mathrm{LA}}-\pi_{\mathrm{pl}}$ in Figure 1; for the sake of comparison, it is expressed per hour of experimental period and per millimeter $\mathrm{Hg}$ difference in transcapillary pressure, based on measurements of the water content of the lungs at autopsy (see Methods). In $11 \mathrm{ex}$ periments in which the mean transcapillary pressure $\left(P_{L A}-\pi_{p l}\right)$ was less than $20 \mathrm{~mm} \mathrm{Hg}$, the rate of accumulation of lung water was $0.16 \mathrm{~g}$ per $\mathrm{g}$ per hour per $\mathrm{mm} \mathrm{Hg}$ or less. In most of the experiments in which the transcapillary pressure difference was greater than $20 \mathrm{~mm} \mathrm{Hg}$, the rates of water accumulation exceeded those observed at values of mean $\mathrm{P}_{\mathrm{LA}}-\pi_{\mathrm{pl}}$ less than $20 \mathrm{~mm} \mathrm{Hg}$.

The patterns of increase in extravascular lung water, based on sequential use of the indicatordilution technique $\left(\mathrm{VTHO}_{\mathbf{L}}\right)$ in group II, are shown in Figure 2. The rate of increase in $\mathrm{VTHO}_{\mathbf{L}}$ appeared to change with time: many animals showed a relatively small increment in $\mathrm{VTHO}_{\mathbf{L}}$ during the first half hour and a much larger increment during the second half hour. The increments in $\mathrm{VTHO}_{\mathrm{L}}$ were statistically significant both at 30 and at 60 minutes $(\mathrm{p}<0.01)$ (Table II).

Group III (high pressure, low gradient). When the left atrial pressure was raised to levels ap-

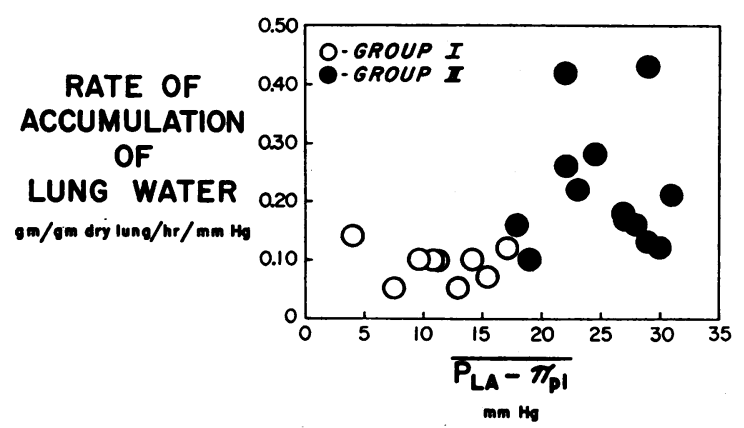

Fig. 1. Rate of accumulation of water in the LUNGS AT DIFFERENT LEVELS OF MEAN TRANSCAPILLARY PRESSURE DIFFERENCE $\overline{\left(\mathrm{P}_{\mathrm{LA}}-\pi_{\mathrm{p} 1}\right)}$. The rate of accumulation of water in the lungs is expressed per unit of mean left atrial and plasma colloid osmotic pressure difference $\overline{\left(\mathrm{P}_{\mathrm{LA}}-\pi_{\mathrm{p} 1}\right)}$. At mean transcapillary pressure differences of less than $20 \mathrm{~mm} \mathrm{Hg}$ (group I), the rate of accumulation of water does not exceed $0.16 \mathrm{~g}$ per $\mathrm{g}$ per hour per $\mathrm{mm} \mathrm{Hg} \Delta \mathrm{P}$; at higher pressure differences (group II), most of the rates of accumulation of water are more rapid.

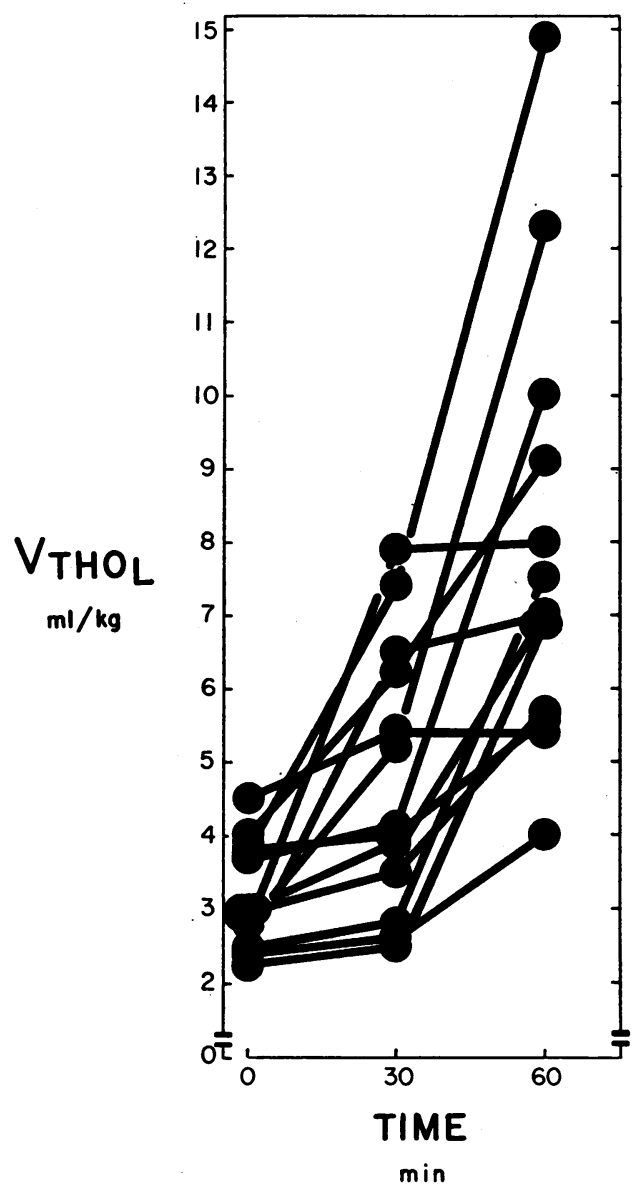

Fig. 2. Serial measurements of extravascular LUNG WATER (VTHOL) AS MEASURED BY INDICATOR-DILUTION TECHNIQUE IN THE 13 DOGS OF GROUP II. The rate of increase in VTHOL during each experiment varied with time even though the transcapillary pressure difference was held constant throughout each experiment. Most of the dogs showed a more rapid increase in VTHOL during the second half hour than during the first half hour.

proximating those of group II, but the transcapillary pressure difference $\left(\mathrm{P}_{\mathbf{L A}}-\pi_{\mathrm{pl}}\right)$ was maintained at low levels comparable to those of group I by the infusion of dextran, the average rate of accumulation of lung water was $1.0 \mathrm{~g}$ per $\mathrm{g}$ per hour $(\mathrm{SE}=0.2)$, or $0.09 \mathrm{~g}$ per $\mathrm{g}$ per hour per $\mathrm{mm} \mathrm{Hg} \Delta \mathrm{P} \quad(\mathrm{SE}=0.02) \quad$ (Table II). This value is identical to that for the mean rate of water accumulation in group I. The indicator-dilution studies (Table II) show no statistically significant increment in $\mathrm{VTHO}_{\mathbf{L}}$ during the first hour, and a significant increase during the second hour $(\mathrm{p}<0.05)$. 


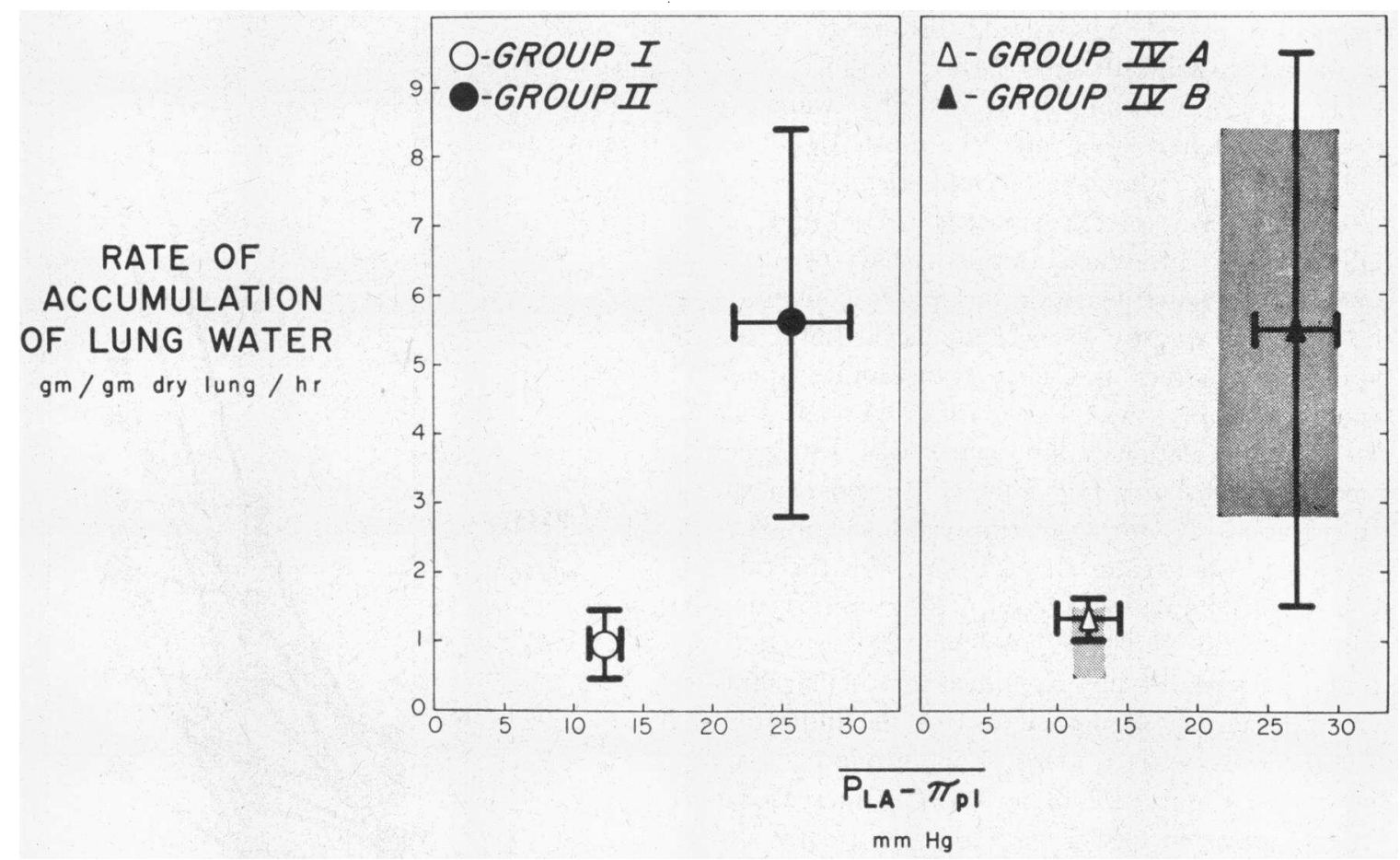

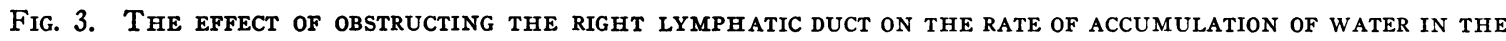
LUNGS. The values are expressed as the mean $\pm 1 \mathrm{SD}$. Left panel: The rate of accumulation of water in the lungs in group I (low pressure, low gradient) is significantly less than in group II (high pressure, high gradient). Right panel: The data from the left panel are shown as shaded backgrounds. Superimposed are the data for the two groups during right lymphatic duct obstruction. There is no statistically significant effect of obstructing lymphatic drainage in these two groups.

Group IV (lymphatic obstruction). The mean rate of water accumulation in lung tissue after obstruction of the right lymphatic duct, at pulmonary venous and colloid osmotic pressure levels similar to those employed in group I, was $1.3 \mathrm{~g}$ per $g$ per hour $(S E=0.1)$, or $0.10 \mathrm{~g}$ per $\mathrm{g}$ per hour per $\mathrm{mm} \mathrm{Hg} \Delta \mathrm{P}(\mathrm{SE}=0.01)$ (Table II). There is no statistically significant difference between this mean and that of group I (Figure 3). The indicator-dilution studies showed no statistically significant increment in $\mathrm{VTHO}_{\mathrm{L}}$ during these experiments $(p>0.05)$.

When the protocol of group II was applied to animals with lymphatic obstruction (group IVB), the mean accumulation rate was $5.5 \mathrm{~g}$ per $\mathrm{g}$ per hour $(\mathrm{SE}=1.8)$, or $0.21 \mathrm{~g}$ per $\mathrm{g}$ per hour per $\mathrm{mm}$ $\mathrm{Hg} \Delta \mathrm{P}(\mathrm{SE}=0.07)$. There is no statistically significant difference between this mean and that of group II (Figure 3). The indicator-dilution studies showed no significant increment in VTHOL during the first half hour $(p>0.05)$ and a sig- nificant increase during the second half hour $(p<0.01)$.

\section{Discussion}

Starling's law. The present study has shown that the bulk movement of water out of the fluidexchanging vessels of the lungs cannot be defined solely in terms of intravascular forces. Two types of experiment are the basis for this conclusion: 1) Serial determinations of the extravascular volume of water, at a constant difference between the intravascular hydrostatic pressure $\left(P_{L A}\right)$ and the osmotic pressure of the plasma proteins $\left(\pi_{\mathrm{pl}}\right)$, using an indicator-dilution technique, showed that the rate of accumulation of lung water is nonlinear with respect to time, and 2) determinations of total water content of the lung at the end of experiments performed at different levels of $\mathrm{P}_{\mathrm{LA}}-\pi_{\mathrm{pl}}$ also showed that the relationship between the rate of accumulation of lung water and the $\mathrm{P}_{\mathrm{LA}}-\pi_{\mathrm{pl}}$ is nonlinear (Figure 4). Theoretically, the non- 


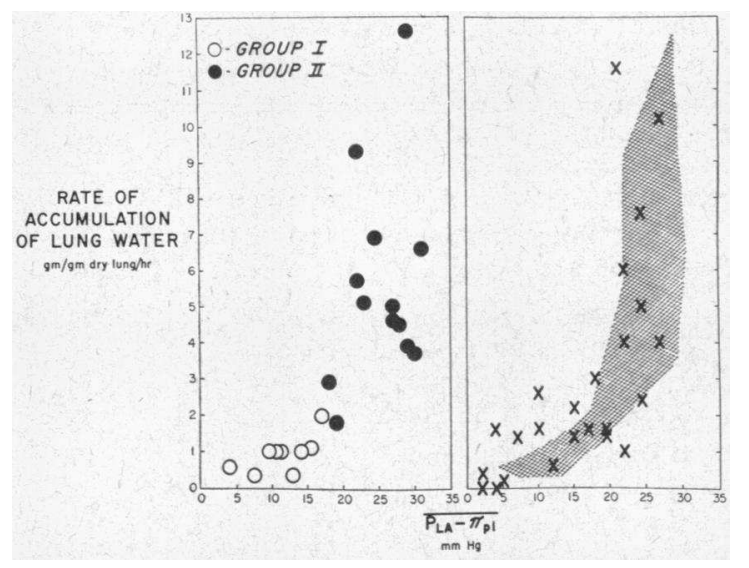

Fig. 4. Comparison of the Results of the PRESENT STUDY With THOSE OF GUYTON AND LindSEY (2). Left panel: Rate of accumulation of water in the lungs, in relation to the average transcapillary pressure difference $\left(P_{L \Delta}-\pi_{p 1}\right)$ in the 9 dogs of group I and in the 13 dogs of group II. The best visual fit of these data appears to be a curve, with more rapid accumulations of lung water at values of $\mathrm{P}_{\mathrm{LA}}-\pi_{\mathrm{p} 1}$ greater than $20 \mathrm{~mm} \mathrm{Hg}$. This conclusion is supported by statistical analysis with the method of weighted least squares (15), which indicates that the linear hypothesis may be rejected $(p<0.01)$. Right panel: The data of Guyton and Lindsey (reference 2, Figure 7) have been recalculated in terms of grams of water accumulated per gram dry lung per hour, with the control data of the present study (lung water $=3.6 \mathrm{~g}$ per g dry lung; plasma colloid osmotic pressure $=16 \mathrm{~mm}$ $\mathrm{Hg}$ ). For comparison, the data of the present study are indicated by the shaded area. The two sets of data correspond closely.

linearity could be due to changes either in the unmeasured pericapillary forces [i.e., the interstitial hydrostatic pressure $\left(\mathrm{P}_{\text {if }}\right)$ or osmotic pressure of interstitial fluid proteins $\left.\left(\pi_{\mathrm{if}}\right)\right]$, in the filtration coefficient $(\mathrm{k})$, or in the lymph drainage from the lungs. Two types of observations in the present experiments support the idea that pericapillary forces $\left(P_{\text {if }}\right.$ or $\left.\pi_{\text {if }}\right)$, rather than a change in the filtration coefficient or in lymph drainage, are responsible for the curvilinear relationship between $\mathrm{P}_{\mathrm{LA}}-\pi_{\mathrm{pl}}$ and the rate of fluid accumulation: 1) For a given $\mathrm{P}_{\mathrm{LA}}-\pi_{\mathrm{pl}}$, higher capillary hydrostatic pressures of the order of $30 \mathrm{~mm} \mathrm{Hg}$, which might be expected to stretch "pores" (16) or to increase capillary surface area, did not increase the rate of accumulation of water in the lungs above values observed at the lower capillary hydrostatic pressures, and 2) obstruction of the right lymphatic duct $(17,18)$ did not alter the rate of accumulation of water in the lungs, either at the high or the low differences between $\mathrm{P}_{\mathbf{L A}}$ and $\pi_{\mathrm{pl}}$.
Pericapillary forces in the edematous lung. Of the two pericapillary forces that could be responsible for nonlinearity in the relationship between the rate of water accumulation and the $\mathrm{P}_{\mathrm{LA}}-\pi_{\mathrm{pl}}$, the hydrostatic pressure of the interstitial fluid seems more likely than the osmotic pressure of the proteins in the pulmonary interstitial spaces. This reasoning is based on the fact that the protein content of the interstitial fluid of lung tissue (19) as well as that of systemic tissues appears to be very low, i.e., of the order of 0.2 to $2.1 \mathrm{~g}$ per $100 \mathrm{ml}$, corresponding to a protein osmotic pressure of 0.1 to $5 \mathrm{~mm} \mathrm{Hg}$ (2). Consequently, the design of the present experiments, which involved hemodilution and marked reduction in the concentration, and therefore in the osmotic pressure, of the plasma proteins made it unlikely that the protein concentration of the interstitial fluid would remain at a high level, or that its osmotic pressure would constituté an appreciable pericapillary force.

Thus, by exclusion, the present experiments suggest that the pericapillary hydrostatic pressure may have an appreciable effect on the exchange of fluid across the pulmonary capillary membrane. Although the nature of the forces responsible for this pericapillary pressure is not entirely clear, it seems that surface tension at the alveolar air-fluid interface may be involved (20). In particular, in the group II experiments of the present study, the heightened surface tension that occurs as fluid accumulates in alveoli $(11,12)$ may, in turn, have contributed to the formation of edema.

A nonlinear rate of accumulation of fluid with respect to $\mathrm{Pc}-\pi_{\mathrm{pl}}$ has been observed in subcutaneous tissues by McMaster (21) and by Guyton (22-24). These studies indicate that 1) transcapillary filtration of water in subcutaneous tissues is associated with a change in pericapillary hydrostatic pressure from a negative to a positive value, 2 ) the accumulation of fluid in the pericapillary interstitium may alter the pressure-volume characteristics of the tissue in such a way as to permit fluid accumulation to continue without progressive increase in tissue pressure, and 3) as interstitial fluid pressure rises above atmospheric, the resistance to the movement of fluid through the tissue spaces decreases markedly.

Similar changes in the interstitial tissue of the lung would be required to explain the observations of the present study. This is demonstrated by 
Figure 5, in which Starling's law of transcapillary exchange is graphically solved for the filtration coefficient $(k)$, at various assumed values of net interstitial fluid pressure $\left(\mathrm{P}_{\mathbf{i f}}-\pi_{\mathrm{if}}\right)$, with the measured values in groups $I$ and II for intravascular pressure $\left(\mathrm{P}_{\mathrm{LA}}-\pi_{\mathrm{pl}}\right)$ and rate of fluid accumulation (F.M.). It may be seen that the curves cross at a $\mathrm{k}$ value of 0.5 to $0.6 \times 10^{-8} \mathrm{ml}$ per second per $\mathrm{cm}^{2}$ per $\mathrm{mm} \mathrm{Hg} \Delta \mathrm{P}$, corresponding to a $\left(\mathrm{P}_{\text {if }}-\pi_{\text {if }}\right)$ of $+10 \mathrm{~mm} \mathrm{Hg}$. With an estimated $\pi_{\text {if }}$ of approximately $3 \mathrm{~mm} \mathrm{Hg}$ (see below), this would require a pericapillary hydrostatic pressure of $+13 \mathrm{~mm} \mathrm{Hg}$, an unlikely situation in a spontaneously breathing animal. At all other values of $\mathrm{P}_{\mathbf{i f}}-\boldsymbol{\pi}_{\text {if }}$ widely different $\mathrm{k}$ values are obtained in the two groups, suggesting either that 1) the permeability of the fluid-exchanging vessels is not a constant but varies somewhat with the experimental circumstances, or 2) if permeability remains unchanged, even the addition of the pericapillary forces considered in the present study $\left(\mathrm{P}_{\text {if }}\right.$ and $\left.\pi_{\text {if }}\right)$ cannot account fully for the continuing accumulation of fluid in lung tissue. By analogy with the observations in subcutaneous tissues (21-24), it seems reasonable that the increase in interstitial fluid pressure that occurs as edema fluid accumulates in lung tissue (25) gives rise to alterations in the pressure-volume characteristics of the interstitial space and in the resistance to

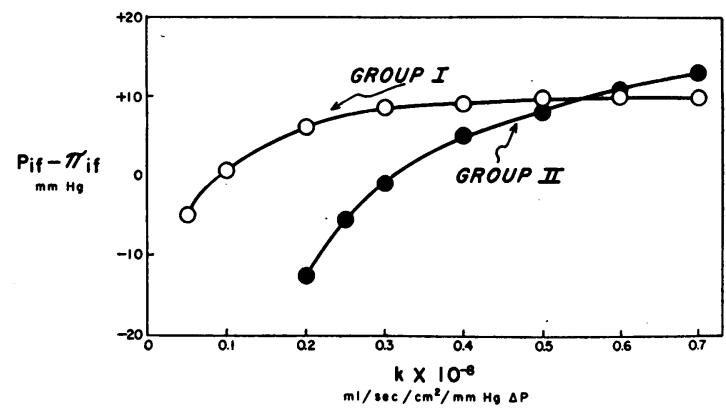

Fig. 5. Graphic solution of Starling's equation: $\left(\mathrm{P}_{1 \mathrm{f}}-\pi_{1 \mathrm{f}}\right)=\left(\mathrm{Pc}-\pi_{\mathrm{pl}}\right)-(\mathrm{F} . \mathrm{M} . / \mathrm{k})$. The mean values for the intravascular transcapillary pressure difference $\left(\mathrm{Pc}-\pi_{\mathrm{p} 1}\right)$ and for the rates of accumulation of lung water (F.M.) in groups I and II have been used to calculate the filtration coefficient $(k)$ for various assumed values of net pericapillary pressure $\left(\mathrm{P}_{1 f}-\pi_{1 f}\right)$. If we assume a single filtration coefficient for the pulmonary capillaries, widely disparate $\mathrm{k}$ values at reasonable levels of $\left(P_{1 f}-\pi_{1 f}\right)$ indicate that in the present study, forces other than those considered in Starling's equation were affecting the rate of accumulation of water in the lungs.
TABLE III

Interstitial fluid volume of lung

\begin{tabular}{llcc}
\hline Species & Indicator & Volume & Reference \\
\hline & & $c m^{3} / g$ lung tissue \\
Dog & Sodium & $0.25 \pm 0.13$ & 27 \\
Dog & Sodium & 0.33 & 28 \\
Human & Sodium & 0.50 & 29 \\
Rabbit & Sucrose & 0.32 & \\
Dog & Sodium & 0.57 & 30 \\
Dog & Chloride & 0.63 & \\
Rabbit & Albumin & 0.26 & 19 \\
\hline
\end{tabular}

fluid movement through interstitial tissue, which in turn modify the rate of fluid accumulation in the lung.

Estimation of normal pericapillary pressure. Granting that Starling's law does apply to the fluid-exchanging vessels of the lungs ("capillaries") (2), the control data of the present experiments (Table I) may be used to estimate the pericapillary hydrostatic pressure in the normal dog lung. For these calculations it is assumed that in the normal lung the net filtration from the vascular system is zero. This assumption is not only reasonable on a priori grounds (since the normal lung is edema-free) but also on the basis of estimates of lymph flow from the lungs. If we assume a pulmonary lymph flow in the normal anesthetized dog of 0.1 to $0.4 \mathrm{ml}$ per $\mathrm{kg}$ body weight per hour (26), it may be calculated that the actual net filtration is normally of the order of $0.1 \mathrm{~g}$ per $\mathrm{g}$ of dry lung tissue per hour. Since there is reason to doubt that all of the measured "pulmonary lymph flow" actually arises from the lungs, even this small flow is probably an overestimate (see below).

In 39 observations, the average pressure in the left atrium was $4 \mathrm{~mm} \mathrm{Hg}$, and the average $\pi_{\mathrm{pl}}$ was $16 \mathrm{~mm} \mathrm{Hg}$, leaving a net absorptive pressure of $12 \mathrm{~mm} \mathrm{Hg}$. From data shown in Table III, the $\pi_{\text {if }}$ of lung tissue was estimated by relating the interstitial fluid volume of lung tissue to the mean content of albumin in the interstitial tissues of the lung (19). Values for the interstitial fluid volume of the lung in several different species are presented in Table III; these were derived from the dilution volumes of indicators known to be distributed in the extracellular compartment, and range from 0.3 to $0.6 \mathrm{ml}$ of interstitial fluid per $\mathrm{g}$ of wet lung (27-30). To compute a maximal 
value for $\pi_{\text {if }}$ in the present study, we made the following assumptions: 1) The minimal value for the interstitial fluid volume of the lung in the normal $\mathrm{dog}$ is $0.3 \mathrm{ml}$ per $\mathrm{g}$ wet lung; 2) the mean content of albumin in normal lung tissue of the dog is the same as that in the rabbit, viz., $3.36 \mathrm{mg}$ per g wet lung (19);3) albumin and globulin are present in lung tissue of the dog in equal concentrations. The osmotic pressures corresponding to albumin and globulin concentrations of 3.36 $\mathrm{mg}$ per $0.3 \mathrm{ml}$, calculated from the empiric equations of Landis and Pappenheimer (2), are 3.0 $\mathrm{mm} \mathrm{Hg}$ and $1.8 \mathrm{~mm} \mathrm{Hg}$, respectively, or a total of $4.8 \mathrm{~mm} \mathrm{Hg}$. A similar computation based on a maximal value for interstitial fluid volume, i.e., $0.6 \mathrm{ml}$ per $\mathrm{g}$ wet lung, provides a minimal estimate of $\pi_{\text {if }}$, viz., $2.4 \mathrm{~mm} \mathrm{Hg}$. If we assume an average of $3 \mathrm{~mm} \mathrm{Hg}$ for $\pi_{\mathrm{if}}$, the net pericapillary hydrostatic pressure is calculated to be approximately $-9 \mathrm{~mm} \mathrm{Hg}$. Values for osmotic pressure of interstitial fluid proteins in other tissues range from 0.1 to $5.0 \mathrm{~mm} \mathrm{Hg} \mathrm{(2).} \mathrm{If} \mathrm{these} \mathrm{val-}$ ues for $\pi_{\text {if }}$ of 0.1 to $5 \mathrm{~mm} \mathrm{Hg}$ are substituted in the Starling equation, the pericapillary pressure $\left(P_{i f}\right)$ of lung tissue at which there would be no net movement of fluid is again of the order of -9 $\mathrm{mm} \mathrm{Hg}$, i.e., -7 to $-12 \mathrm{~mm} \mathrm{Hg}$. All of these values for pericapillary pressure in the lungs are also of the same order of magnitude as the -7 $\mathrm{mm} \mathrm{Hg}$ obtained by Guyton from capsules in subcutaneous tissues (22).

Two aspects of the present study warrant further consideration with respect to the estimation of pericapillary pressure: 1) Both the control left atrial pressures and the control colloid osmotic pressures of the plasma were somewhat lower than those reported by others $(31,32)$; the reasons for these discrepancies are not clear. However, the difference between the more conventional values for left atrial pressure ( 7 to $10 \mathrm{~mm} \mathrm{Hg}$ ) and for plasma colloid osmotic pressure (17 to 22 $\mathrm{mm} \mathrm{Hg}$ ) is still the same as in the present study, and the pericapillary pressure is again calculated to be $-9 \mathrm{~mm} \mathrm{Hg}$. 2) The left atrial pressure was used as a measure of pulmonary "capillary" pressure. In the present experiments the differences between mean pulmonary arterial and mean left atrial pressures averaged $7 \mathrm{~mm} \mathrm{Hg}$. If pulmonary capillary pressure is assumed to exceed left atrial pressure by one-half of this difference, the pericapillary hydrostatic pressure would not be markedly changed, i.e., from -9 to $-6 \mathrm{~mm}$ $\mathrm{Hg}$.

The flow of pulmonary lymph. The presence of a negative interstitial pressure in normal lungs raises a question as to the driving force for the flow of lymph from the lungs (subatmospheric pressure) to the systemic veins (above atmospheric pressure). One possible explanation for this relationship is that the flow of pulmonary lymph occurs only during periods of increased intrathoracic pressure such as coughing, i.e., when intrapleural (and pulmonary interstitial pressure) exceeds systemic venous pressure. These pressure relationships also suggest that experiments which provide a continuous flow of lymph from the right lymphatic duct have either upset the normal pressure gradients from pulmonary lymphatics to systemic veins, e.g., by thoracotomy, or are collecting lymph that does not derive entirely from the pulmonary lymphatics, e.g., from the pleura, pericardium, and peritoneum (26).

Filtration coefficients. Since the bulk flow of water in tissues does follow Starling's law, filtration coefficients have been found to be useful for comparing the permeability characteristics of different tissues (2). Filtration coefficients for the dog lung can be calculated from the data of groups I and II by substitution in Starling's law, assuming that the interstitial fluid pressure $\left(P_{i f}\right)$ approaches and exceeds zero as interstitial edema accumulates $(23,25)$. The filtration coefficient, $\mathrm{k}$, is expressed per square centimeter of capillary surface area; the alveolar surface area of the dog, approximately $50 \mathrm{~m}^{2}(33)$, is taken as an estimate of the pulmonary capillary surface area for the dogs of groups I and II, having an average body weight of $14 \mathrm{~kg}$ and an average dry lung weight of $23 \mathrm{~g}$. For a $\left(\mathrm{P}_{1 f}-\pi_{\text {if }}\right)$ of zero, the filtration coefficient calculated from the mean data of group I is $0.12 \times 10^{-8}$, and from the mean data of group II, $0.26 \times 10^{-8} \mathrm{ml}$ per second per $\mathrm{cm}^{2}$ per $\mathrm{mm} \mathrm{Hg}$ $\Delta \mathrm{P}$. These values, used only as an indication of the order of magnitude of the true filtration coefficient for lung tissue, are approximately one-tenth to one-twentieth that of canine muscle capillaries (2).

\section{Acknowledgments}

We are grateful to Professor Richard Skalak for many animated discussions, to Dr. Lyon Hyams for statistical advice, and to Mr. Robert J. Molz and Miss Mildred Daise for technical assistance. 


\section{References}

1. Starling, E. H. On the absorption of fluids from the connective tissue spaces. J. Physiol. (Lond.) $1896,19,312$.

2. Landis, E. M., and J. R. Pappenheimer. Exchange of substances through the capillary walls in Handbook of Physiology, sect. 2, vol. 2, Circulation, W. F. Hamilton and P. Dow, Eds. Washington, D. C., American Physiological Society, 1963.

3. Wiederhielm, C. A. Analysis of small vessel function (abstract) in Physical Bases of Circulatory Transport: Regulation and Exchange. Aspen, Colo., September 1966.

4. Guyton, A. C., and A. W. Lindsey. Effect of elevated left atrial pressure and decreased plasma protein concentration on the development of pulmonary edema. Circulat. Res. 1959, 7, 649.

5. Levine, O. R., R. B. Mellins, and A. P. Fishman. Quantitative assessment of pulmonary edema. Circulat. Res. 1965, 17, 414.

6. Hayward, G. W. Pulmonary oedema. Brit. med. J. $1955,1,1361$.

7. Gorlin, R., B. M. Lewis, F. W. Haynes, R. J. Spiegl, and L. Dexter. Factors regulating pulmonary "capillary" pressure in mitral stenosis. Amer. Heart J. 1951, 41, 834.

8. Dexter, L., J. W. Dow, F. W. Haynes, J. L. Whittenberger, B. G. Ferris, W. T. Goodale, and H. K. Hellems. Studies of the pulmonary circulation in man at rest. Normal variations and the interrelations between increased pulmonary blood flow, elevated pulmonary arterial pressure, and high pulmonary "capillary" pressures. J. clin. Invest. 1950, 29, 602.

9. Araujo, J., and D. S. Lukas. Interrelationships among pulmonary "capillary" pressure, blood flow and valve size in mitral stenosis. The limited regulatory effects of the pulmonary vascular resistance. J. clin. Invest. 1952, 31, 1082.

10. Bruderman, I., K. Somers, W. K. Hamilton, W. H. Tooley, and J. Butler. Effect of surface tension on circulation in the excised lungs of dogs. J. appl. Physiol. 1964, 19, 707.

11. Johnson, J. W. C., S. Permutt, J. H. Sipple, and E. S. Salem. Effect of intra-alveolar fluid on pulmonary surface tension properties. J. appl. Physiol. 1964, 19, 769.

12. Said, S. I., M. E. Avery, R. K. Davis, C. M. Banerjee, and M. El-Gohary. Pulmonary surface activity in induced pulmonary edema. J. clin. Invest. $1965,44,458$.

13. Neuhausen, B. S., and D. M. Rioch. The refractometric determination of serum proteins. J. biol. Chem. 1923, 55, 353.

14. Chinard, F. P., and T. Enns. Transcapillary pulmonary exchange of water in the dog. Amer. J. Physiol. 1954, 178, 197.

15. Williams, E. J. Regression Analysis. New York, John Wiley, 1959.

16. Shirley, H. H., Jr., C. G. Wolfram, K. Wasserman, and H. S. Mayerson. Capillary permeability to macromolecules: stretched pore phenomenon. Amer. J. Physiol. 1957, 190, 189.

17. Uhley, H., S. E. Leeds, J. J. Sampson, and M. Friedman. Some observations on the role of the lymphatics in experimental acute pulmonary edema. Circulat. Res. 1961, 9, 688.

18. Rabin, E. R., and E. C. Meyer. Cardiopulmonary effects of pulmonary venous hypertension with special reference to pulmonary lymphatic flow. Circulat. Res. 1960; 8, 324.

19. Rothschild, M. A., M. Oratz, C. D. Evans, and S. S. Schreiber. Role of hepatic interstitial albu$\mathrm{min}$ in regulating albumin synthesis. Amer. J. Physiol. 1966, 210, 57.

20. Clements, J. A. Pulmonary edema and permeability of alveolar membranes. Arch. environm. Hlth 1961, 2, 280.

21. McMaster, P. D. Factors influencing the intermittent passage of Locke's solution into living skin. J. exp. Med. 1941, 73, 85.

22. Guyton, A. C. A concept of negative interstitial pressure based on pressures in implanted perforated capsules. Circulat. Res. 1963, 12, 399.

23. Guyton, A. C. Interstitial fluid pressure: II. Pressure-volume curves of interstitial space. Circulat. Res. 1965, 16, 452.

24. Guyton, A. C., and K. Scheel. Interstitial fluid pressure. III. Its effect on resistance to tissue fluid mobility. Circulat. Res. 1966, 19, 412.

25. West, J. B., C. T. Dollery, and B. E. Heard. Increased pulmonary vascular resistance in the dependent zone of the isolated dog lung caused by perivascular edema. Circulat. Res. 1965, 17, 191.

26. Courtice, F. C. Lymph flow in the lungs. Brit. med. Bull. 1963, 19, 76.

27. Taylor, A. E., A. C. Guyton, and V. S. Bishop. Permeability of the alveolar membrane to solutes. Circulat. Res. 1965, 16, 353.

28. Chinard, F. P., T. Enns, and M. F. Nolan. Pulmonary extravascular water volumes from transit time and slope data. J. appl. Physiol. 1962, 17, 179.

29. Bauman, A., M. A. Rothschild, R. S. Yalow, and S. A. Berson. Pulmonary circulation and transcapillary exchange of electrolytes. J. appl. Physiol. 1957, 11, 353.

30. Fishman, A. P., E. L. Becker, H. W. Fritts, Jr., and H. O. Heinemann. Apparent volumes of distribution of water, electrolytes and hemoglobin within the lung. Amer. J. Physiol. 1957, 188, 95.

31. Hellems, H. K., F. W. Haynes, L. Dexter, and T. D. Kinney. Pulmonary capillary pressure in animals estimated by venous and arterial catheterization. Amer. J. Physiol. 1948, 155, 98.

32. Kerkhof, A. C. Plasma colloid osmotic pressure as a factor in edema formation and edema absorption. Ann. intern. Med. 1937, 11, 867.

33. Tenney, S. M., and J. E. Remmers. Comparative quantitative morphology of the mammalian lung: diffusing area. Nature (Lond.) 1963, 197, 54. 